\title{
Verification of VVER-1200 NPP Simulator in Normal Operation and Reactor Coolant Pump Coast-Down Transient
}

\author{
Le Dai Dien', Do Ngoc Diep² \\ ${ }^{1}$ Nuclear Training Center, VINATOM, Hanoi, Vietnam \\ ${ }^{2}$ Vietnam Atomic Energy Agency, Hanoi, Vietnam \\ Email: daidienle@gmail.com,dndiep@most.gov.vn
}

How to cite this paper: Dien, L.D. and Diep, D.N. (2017) Verification of VVER1200 NPP Simulator in Normal Operation and Reactor Coolant Pump Coast-Down Transient. World Journal of Engineering and Technology, 5, 507-519.

https://doi.org/10.4236/wjet.2017.53043

Received: June 2, 2017

Accepted: August 18, 2017

Published: August 21, 2017

Copyright $\odot 2017$ by authors and Scientific Research Publishing Inc. This work is licensed under the Creative Commons Attribution International License (CC BY 4.0). http://creativecommons.org/licenses/by/4.0/

\section{Open Access}

\begin{abstract}
Verification of operation parameters of VVER-1200 NPP Simulator installed at Nuclear Training Center, VINATOM has been performed. This simulator has been supplied for Vietnam in the framework of IAEA TC Project VIE2010 on Developing Nuclear Power Infrastructure-Phase II hosted by the Vietnam Atomic Energy Agency (VAEA). The comparison of the main parameters in nominal power operation with design data given in safety analysis report of VVER-1200/V392M as well as Ninh Thuan FSSAR is presented. In this study, the reactor coolant coast-down transient is investigated using the VVER-1200 NPP simulator. The simulated results performed in the simulator through switching off one reactor coolant pump in comparisons with experiment results performed in VVER-1000 reactor are given. The similarity between the measured and simulated results shows that the thermal hydraulic characteristics and the control protection systems are modeled in a reasonable way. A good agreement in operating parameters was found between the VVER-1200 NPP simulator and VVER-1200/V392M's PSAR.
\end{abstract}

\section{Keywords}

Simulator, Human Machine Interfaces, VVER Type Reactor, Reactor Coolant Pump, Control Rod Bank

\section{Introduction}

In the design of pressurized water reactor (PWR), the reactor coolant pump (RCP) is one of the important components in the nuclear steam supply system (NSSS). The RCP forces the coolant through the reactor core and steam generator to maintain a balance of heat transfer in a coolant loop. The operating conditions 
of the RCP have an important influence on the coolant mass flow rate and thermal behavior of NSSS. For instant, in accident conditions with loss of power supply, the RCP ensures coolant circulation in the coast-down to permit a smooth transition to the natural circulation mode [1].

Investigation of flow transients in reactor coolant system due to the RCP coast-down is not only important in the safety analysis, but also in normal operations of VVER as well as Western PWR reactors due to decrease of coolant flow through the core. For PWR, such as KWU PWR design, one RCP trip did not make reactor trip, instead operation is continued at reduced power [2]. However, in Westinghouse design, if a RCP trips at power levels greater than $10^{-4} \%$ of nominal power, a reactor trip will occur [3]. Thus, operation with one or two RCPs switched off is a noticeable feature of VVER nuclear power plant (NPP). Several reactor operation transients and international benchmarks for investigating and evaluating the RCP switching off and on have been performed. The benchmarks were carried out in the VVER-1000 NPPs by switching off one of four working RCPs in commissioning experiment at Balakovo-1 [4]. In EUPHARE SRR 195 project at Balakovo-4 [4] the benchmarks of switching off of one of two working feed water pumps were done. In particular, switching on of one from three working RCPs in the EU VALCO project at Kozloduy-6 [4] and switching-off of one of four operating RCPs at nominal reactor power in the coolant transient benchmark-Kalinin-3 (NEA/OECD) [5] were benchmarked. The purpose of these benchmarks is verification and validation of the models used in simulation codes. Many experiments and simulations are also carried out by Russian researchers on the VVER-1000/V320 NPPs. In this study, the measurements carried out in Rostov unit-1 [6] are used and the results are compared with those obtained in the simulator. It is also noted that the first VVER-1200 NPP has been put into operation since August 2016 [7]. Thus, the further studies using the simulator should be compared with available data from the real plant in the future.

The purpose of this work is to verify operation parameters of the simulator to confirm that the VVER-1200/V392M is simulated in the simulator through comparison with VVER-1200 SAR [8] [9]. The real-time simulation was also investigated through switching off one RCP in comparisons with PSAR [9] and experiments conducted in VVER-1000 reactor [6].

\section{Verification of Simulator in Nominal Power Operation}

\subsection{VVER-1200 Is an Evolution of VVER-1000 Reactor}

According to PSAR and FSSAR of VVER-1200 [8] [9], the reactor is operated with four loops at nominal power. At the reduced power levels to $67 \%, 50 \%$ and $40 \%$ the reactor is operated with three loops, two opposite loops and two adjacent loops, respectively.

The VVER-1200 reactor is an evolution of the VVER-1000 reactor. VVER1200 and NSSS are designed by Gidro Press in an attempt to improve performance and safety of the reactor. The design of VVER-1200 is based on more 
than 1400 reactor-year experiences in operation of VVER [10]. There are two versions named VVER-1200/V491 and VVER-1200/V392M (Figure 1) with different design of safety systems developed by JSC SPb AEP, St. Peterburg and JSC Atom Energo Proekt, Moscow.

The main differences between two designs are the safety systems. For example, in the VVER-1200/V392M design, the safety system consists of two-stage

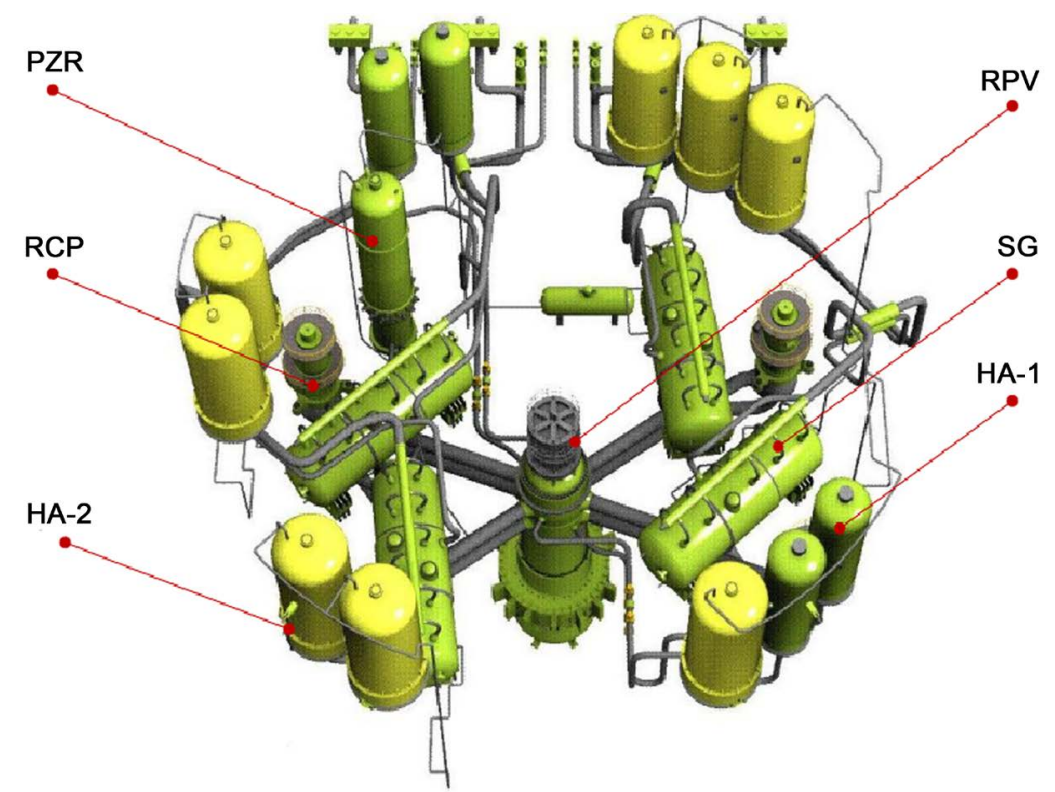

Figure 1. VVER-1200/V392M Nuclear Steam Supply System [7].

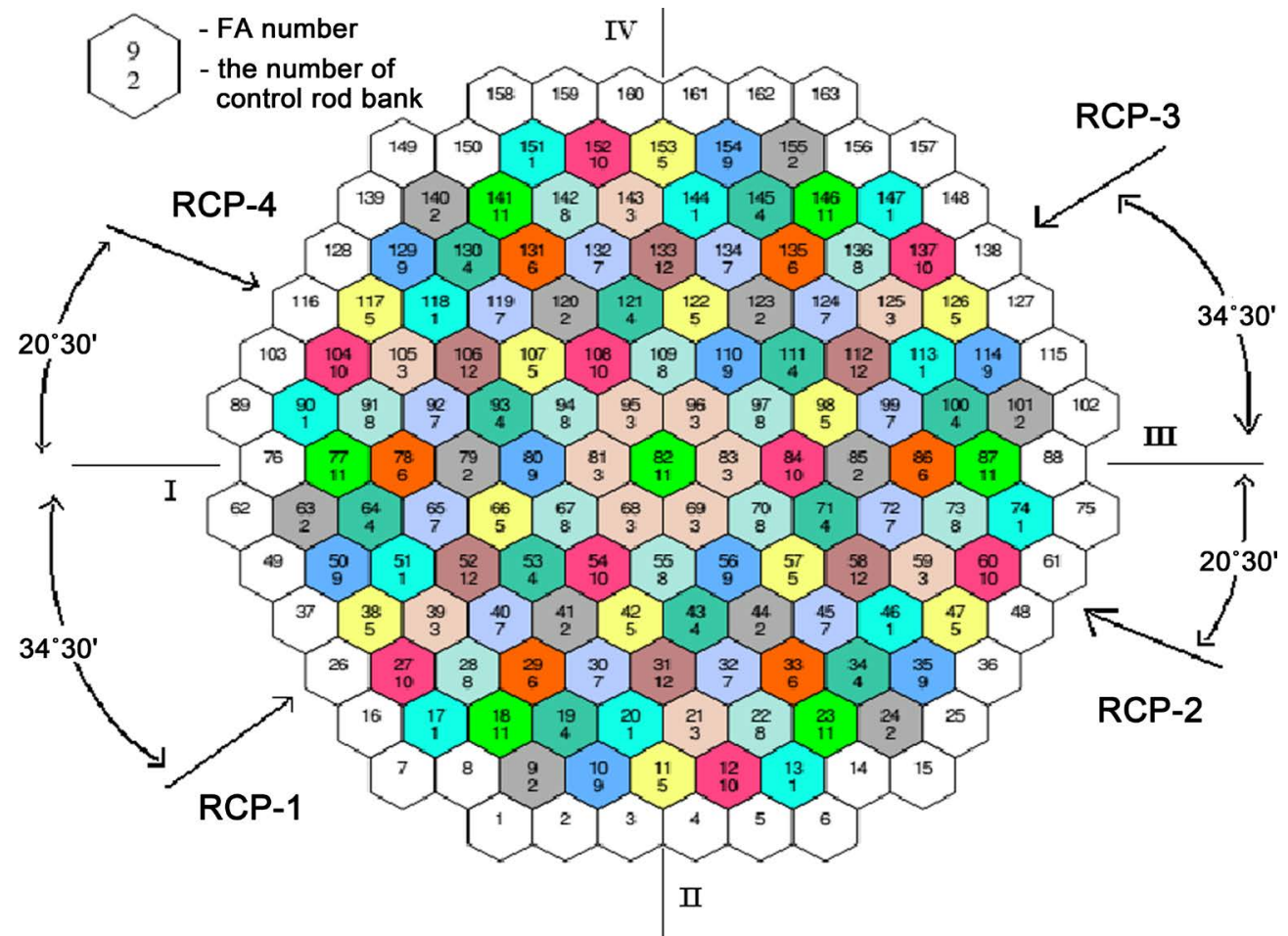

Figure 2. Reactor core with control rod banks (The arrows show the nominal positions of the inlet nozzles). 


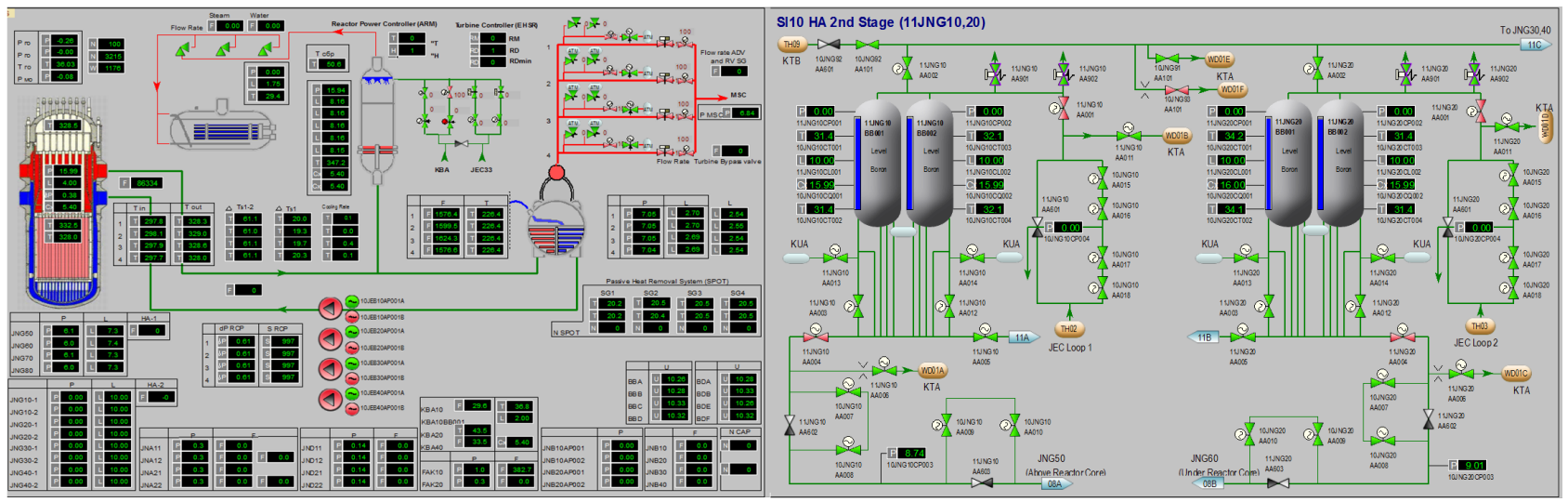

Figure 3. HMI of primary system and second stage hydro accumulators (HA-2) in the simulator.

Hydro Accumulators (HA-1 and HA-2) as seen in HMI of the simulator [11] (Figure 3.)

For the reactor pressure vessel (RPV) of VVER-1200, the major developments based on VVER-1000 are:

- Increase of RPV dimensions provides essential decrease in radiation impact on the RPV wall [12] with height from $10,897 \mathrm{~mm}$ to $11,185 \mathrm{~mm}$, inner diameter from $4150 \mathrm{~mm}$ to $4250 \mathrm{~mm}$ and wall thickness (core shell) from $192.5 \mathrm{~mm}$ to $197.5 \mathrm{~mm}$. The fuel length changes from $3530 \mathrm{~mm}$ to $3730 \mathrm{~mm}$, so that the reactor power increases while the total number of fuel assemblies (FA) in reactor core is kept unchanged (163 FAs).

- In VVER-1000, there are 61 control rods divided into 10 groups (banks) while there are up to 121 control rods divided into 12 groups in VVER-1200 design (Figure 2). The absorbing materials are $\mathrm{B} 4 \mathrm{C}$ and $\mathrm{Dy}_{2} \mathrm{O}_{3} \mathrm{TiO}_{2}$ while only $\mathrm{B}_{4} \mathrm{C}$ used in VVER-1000.

From thermal-hydraulics aspect, it is reasonable to compare the experiment with the simulation results owing to no large changes in geometry of reactor pressure vessel

\subsection{Technical Features of the Simulator}

The simulator is supplied by Western Service Co. (WSC), US with 3KEYMASTER ${ }^{\mathrm{mx}}$ modeling tools which include 3 KEYMASTER $^{\text {mo }}$ Instructor Station, The simulator covers the full range of plant operations from plant cold shutdown to hot standby, hot zero power, and to full range of power maneuvers as well as all possible transients. These models combine to form the engineering simulator as defined by IAEA [13].

The simulator can be operated in real-time or accelerated time mode. The advantage of using a real-time simulator is that user can understand the response of the systems which correctly represents the real system, without delay or limitations as pre-recorded scenarios. The evolution of NPP simulators with real time is described in [14].

The simulator is intended to simulate the VVER-1200/V392M technology [11]. It consists of more than 150 human machine interfaces (HMIs) which 
represent the technology schemes of NPP. The HMIs cover from component cooling system $(\mathrm{CC})$, containment $(\mathrm{CH})$, condensate pump $(\mathrm{CP})$, reactor core (CR), chemical and volume control system (CVCS), condenser water (CW), electrical systems (ED, EG), feedwater (FW), heating and ventilation system $(\mathrm{HV})$, instrumentation air (IA), main steam (MS), control system (Control), safety systems (RD, SI), service water (SW), turbine systems (TC, TU) and waste processing systems (WD).

\subsection{Verification of the Simulator in Nominal Power Operation}

Verification of simulator for normal operation and transients has been performed. To shorten the time to start-up and bring reactor into critical state and full power operation, the ICs (Initial Condition) are set up so that user can start operate the reactor in predefined scenarios. The beginning of cycle (BOC) is initiated and main parameters for normal operation are reported in Table 1 . The parameters are in compliance with design data [8] [9]. So, it is expected to ensure that specified learning objectives can be achieved and the simulator performs in accordance with VVER-1200 NPP design. The following section describes a transient with one RCP coast-down. This is intended to verify a realtime simulation as well as response of the simulator.

\section{Simulation of Reactor Coolant Pump Coast-Down Transient}

\subsection{RCP Coast-Down Transient and Sequence of Events}

In the operation of VVER-1200 which permits one or two RCPs to be switched

Table 1. Comparison of NPP parameters in nominal power operation.

\begin{tabular}{|c|c|c|c|}
\hline Parameter & $\begin{array}{l}\text { VVER1200 } \\
\text { Simulator }\end{array}$ & $\begin{array}{l}\text { Ninh Thuan } \\
\text { Project [8] }\end{array}$ & $\begin{array}{l}\text { NNPP-2 } \\
\text { PSAR [9] }\end{array}$ \\
\hline Reactor thermal power, MW & 3212 & 3212 & $3200+128$ \\
\hline Nominal electric power, MW & $1178-1183$ & 1186 & 1198 \\
\hline Reactor Outlet pressure, $\mathrm{MPa}$ & $15.9 \div 16.1$ & $16.2 \pm 0.3$ & $16.2 \pm 0.3$ \\
\hline Reactor coolant flow rate, $\mathrm{m}^{3} / \mathrm{h}$ & $86,333 \pm 5$ & $88,000(+2100-3100)$ & $86,000 \pm 2900$ \\
\hline Reactor coolant inlet temperature, ${ }^{\circ} \mathrm{C}$ & 297.6 & $298.2+2 /-4$ & $298.2+2 /-4$ \\
\hline Reactor coolant outlet temperature, ${ }^{\circ} \mathrm{C}$ & 328.8 & $328.6 \pm 4$ & $328.9 \pm 5$ \\
\hline Reactor heat up, ${ }^{\circ} \mathrm{C}$ & 30.5 & 30.7 & 30.7 \\
\hline Pressurizer level, m & $8.13 \pm 0.01$ & $8.17 \pm 0.15$ & $8.17 \pm 0.15$ \\
\hline SG water level, $\mathrm{m}$ & $2.7 \pm 0.01$ & $2.7 \pm 0.05$ & $2.7 \pm 0.05$ \\
\hline SG steam pressure, $\mathrm{MPa}$ & $7.0 \pm 0.02$ & $7.0 \pm 0.1$ & $7.0 \pm 0.1$ \\
\hline Feed water temperature, ${ }^{\circ} \mathrm{C}$ & $226.8 \pm 0.15$ & $225 \pm 5$ & $225 \pm 5$ \\
\hline Feed water flow in SG1/2/3/4, t/h & $1614 \div 1668$ & $1602(+112)$ & $1602(+112)$ \\
\hline $\begin{array}{l}\text { Operation at load of (\% Nnom): } \\
\begin{aligned}- & 4 \text { RCPs } \\
& -3 \text { RCPs } \\
- & 2 \text { RCPs (opposite) } \\
- & 2 \text { RCPs (adjacent) }\end{aligned}\end{array}$ & $\begin{array}{c}100 \% \\
66 \% \\
49.5 \% \\
40 \%\end{array}$ & $\begin{array}{c}100 \% \\
67 \% \\
50 \% \\
40 \%\end{array}$ & $\begin{array}{c}100 \% \\
67 \% \\
50 \% \\
40 \%\end{array}$ \\
\hline
\end{tabular}


off, the reactor control is equipped with preventive emergency protection system [9]. The signals from the system initiates control protection system (CPS) with control rods and drives will reduce power or prohibit power rise, so that it can avoid the reactor trip and prevent violation of safety limits and conditions. Fast power setback (FPS) system automatically reduces reactor power by insertion of automatic control banks by power setback-1 (PS-1) and prohibits reactor power rise by prohibiting withdrawal of the CPS rods. Figure4a shows the flow rate of RCP-1391 of VVER-1200 NPP and its rotation speed when one out of four operating RCPs trips compared with the results obtained in the simulator (Figure 4(b)). RCP \#3 as seen in Figure 3 is switched off in the simulator for analysis.

Two seconds after the RCP switch-off, the power control system responded by inserting the control rod bank \#7 from top to bottom within four seconds. As a result, the core power decreased down to about $61 \%$ of nominal power within 10 s. Also, the control rod bank \#12 started moving in at a rate of $2 \mathrm{~cm} / \mathrm{s}$. The initial axial position was at $317.2 \mathrm{~cm}$. The slow insertion of control rod bank \#12 down to an axial position of $281 \mathrm{~cm}$ resulted in a further power decrease to about $55 \%$ of nominal power.

The reactor was stabilized at the level of $64 \%$ by the automatic power control with the move up of bank \#12 to the position of $327 \mathrm{~cm}$. Due to RCP-3 switchoff, the mass flow rate decreases and then the reverse flow from cold leg to hot leg of this loop is started within 23 seconds. Initially, the primary pressure decreased, later on the primary pressure increased again to maintain the heat balance. The sequence of main events is given in Table 2.

\subsection{Variation of Operation Parameters during Transient}

The decrease of mass flow rate through reactor core (Figure 5) will make fuel

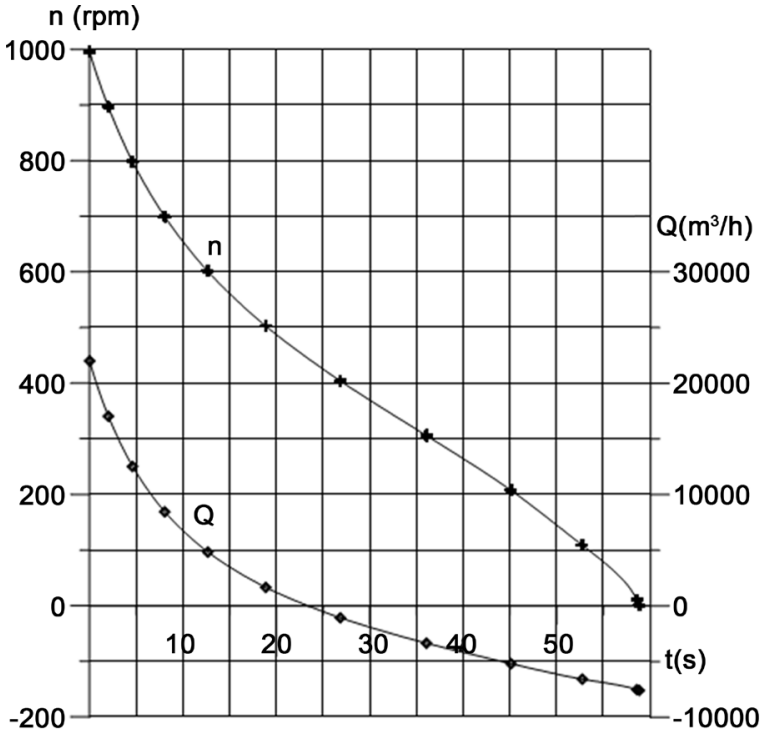

(a)

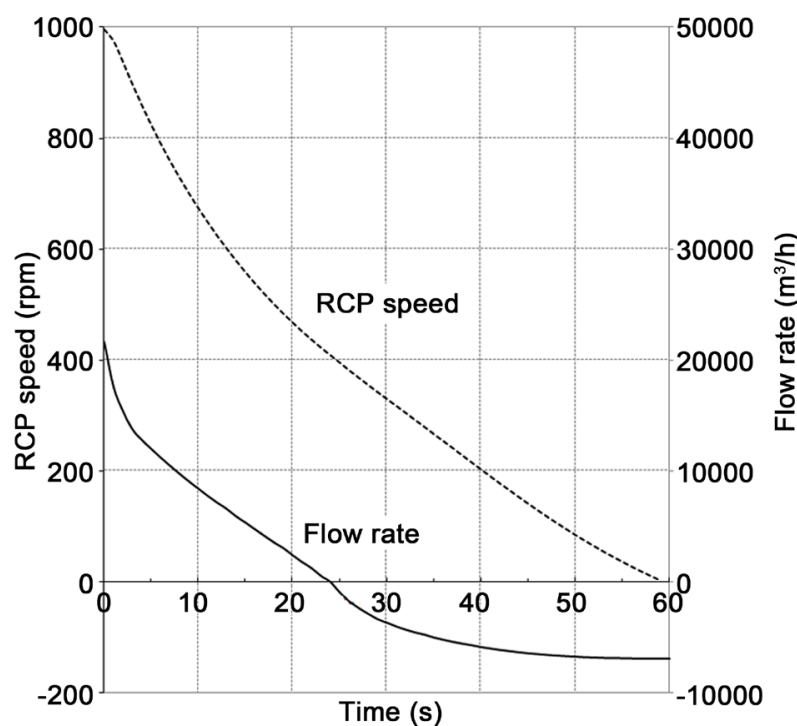

(b)

Figure 4. Mass flow rate of RCP and rotation speed when one out of four operating RCPs trips [9] (a) and observed in the simulator (b). 
Table 2. Sequence of main events.

\begin{tabular}{cc}
\hline Time, s & Event \\
\hline 0 & RCP \#3 is switched off \\
2 & Control rod bank \#7 drops into the core within $4 \mathrm{~s}$ \\
3 & PZR heater (Group \#1) is on \\
10 & Bank \#12 moves in at a rate of $2 \mathrm{~cm} / \mathrm{s}$ \\
13 & PZR heaters (Group \#3, 4) are on \\
23 & Reverse flow from cold leg to hot leg of loop \#3 started \\
35 & Temperature in hot leg \#3 decreases lower than cold leg \\
55 & Mass flow rate through reactor core reaches steady state \\
285 & PZR heaters (Group \#3, 4) are off \\
350 & PZR water level and core pressure are stabilized \\
420 & End of transient \\
\hline
\end{tabular}

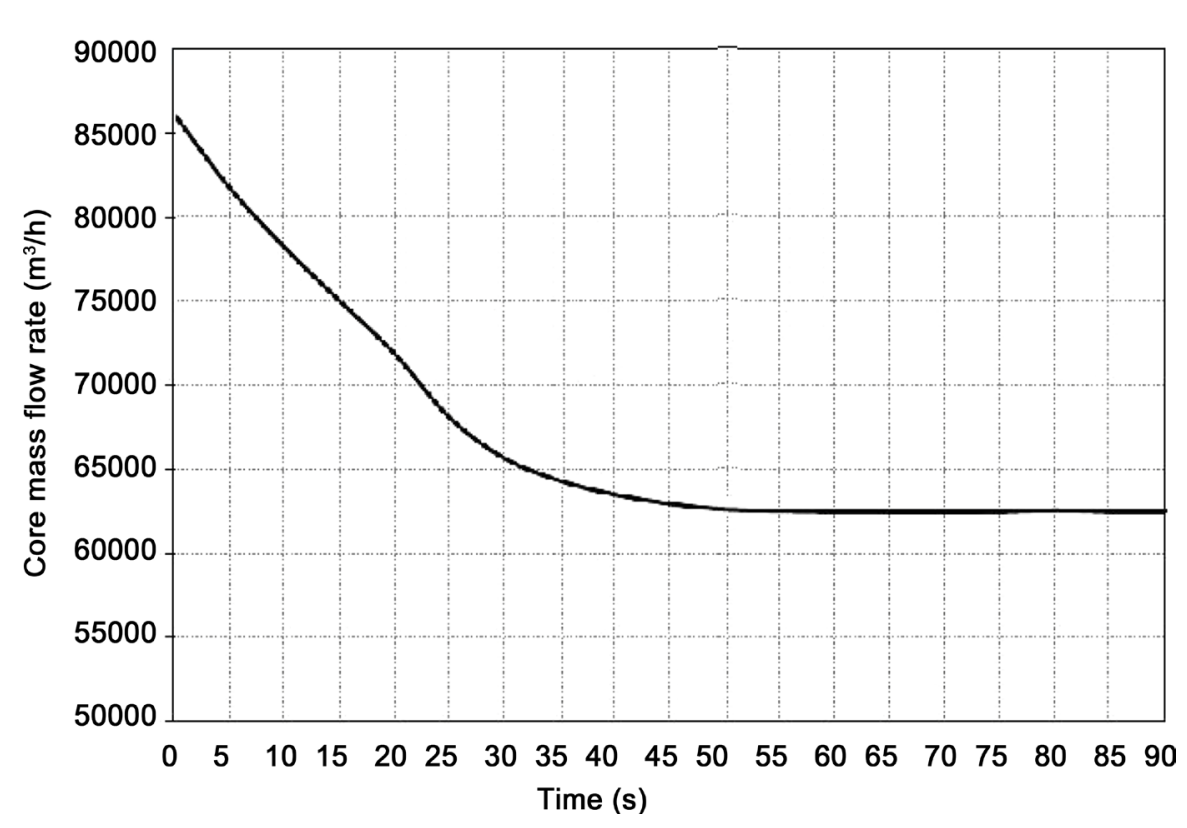

Figure 5. Coolant mass flow rate through reactor core.

and coolant temperatures slightly higher, resulting in a small negative reactivity insertion within 30 seconds as seen in Figure 6. However, the negative reactivity insertion is resulted by the drop of control rod bank \#7 (Figure 9(b)). From Figure 6, it is seen that the reactivity insertion by control rods get the maximum value of $-0.4 \% \Delta \mathrm{k} / \mathrm{k}$ within 1.5 seconds.

As seen in Figure 7(b) the temperature in cold leg (inlet nozzle) at first decreases as reactor power decreases. After that it increases due to RCP coast-down finished within 23 seconds and reverse flow through the loop is initiated (Figure 4(b)). This results in the decrease of average temperature in upper plenum and difference in the thermal power of SG in the operating loops.

As three main coolant pumps continued operating, the temperature differences between these hot legs and the corresponding cold legs decreased proportionally to the thermal power reduction. Then temperature in the loops stabilized at a new level. The temperature difference between cold legs and hot legs is 
similar for simulator and VVER-1000 measurements as seen in Figure 7(a), Figure 7(b) and Figure 8(a), Figure 8(b), respectively.

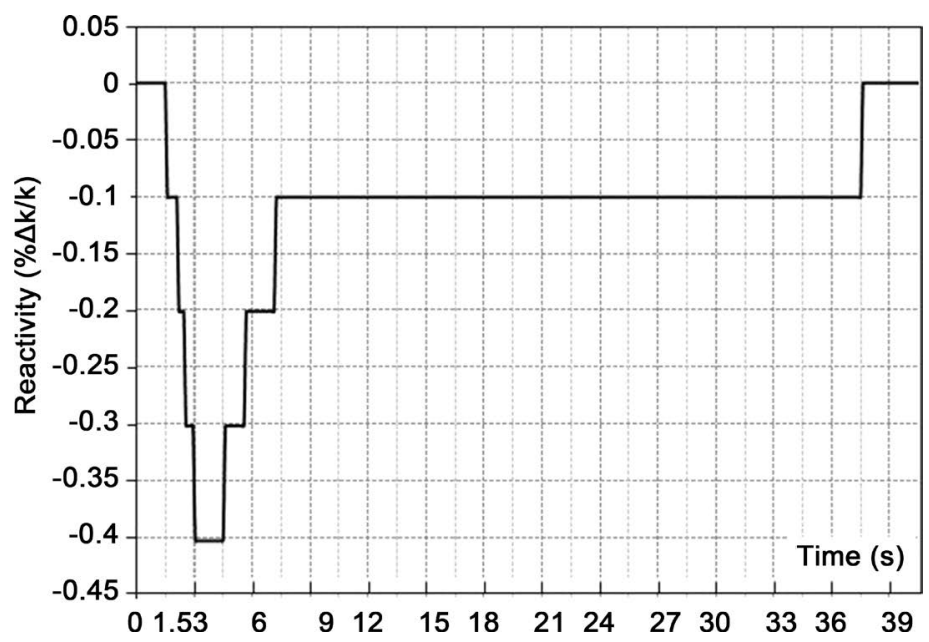

Figure 6. Variation of reactivity during transient.

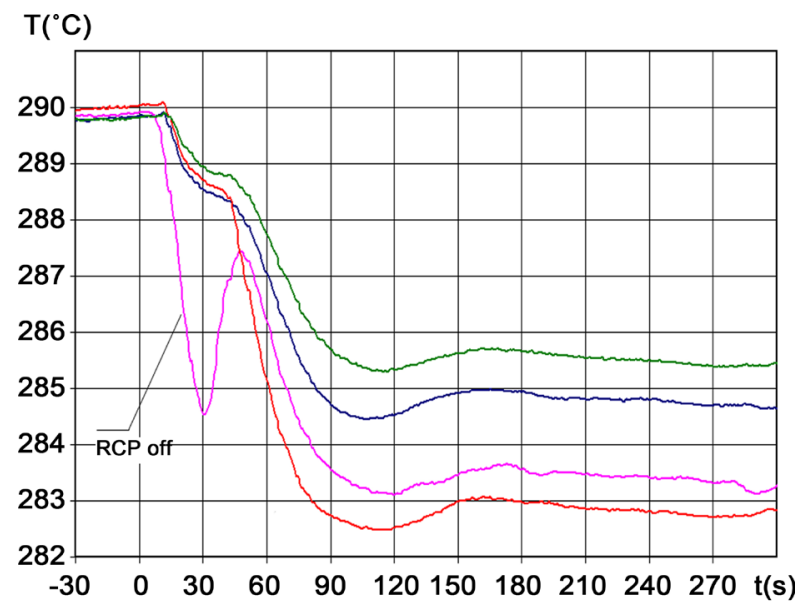

(a)

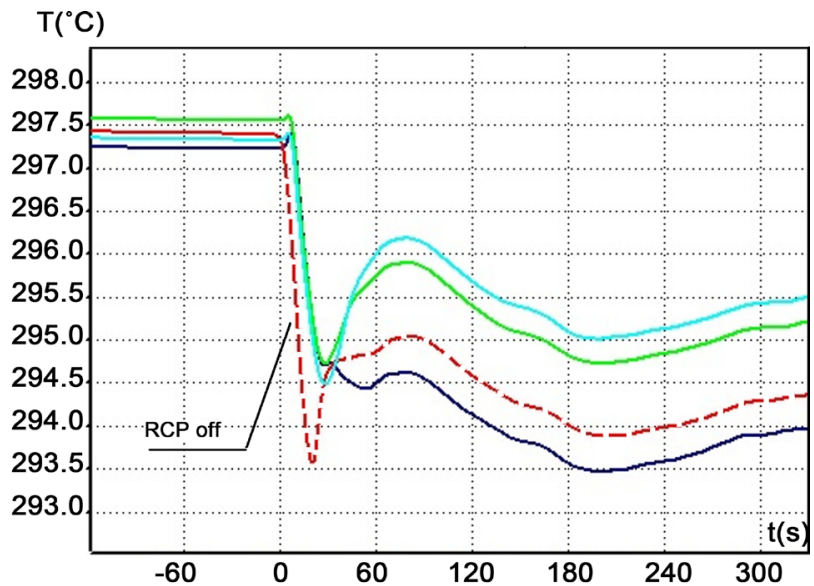

(b)

Figure 7. (a) Changes of coolant average temperature in cold legs measured in VVER-1000 [6]; (b) Changes of coolant average temperature in cold legs simulated by the simulator.

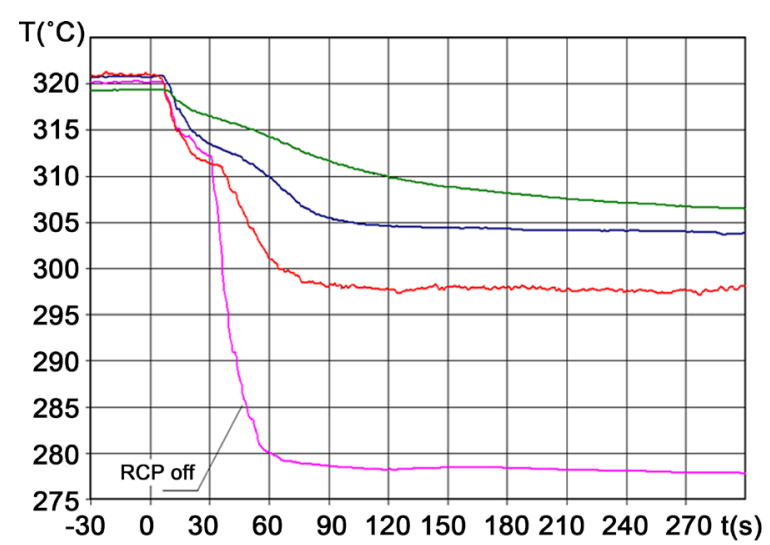

(a)

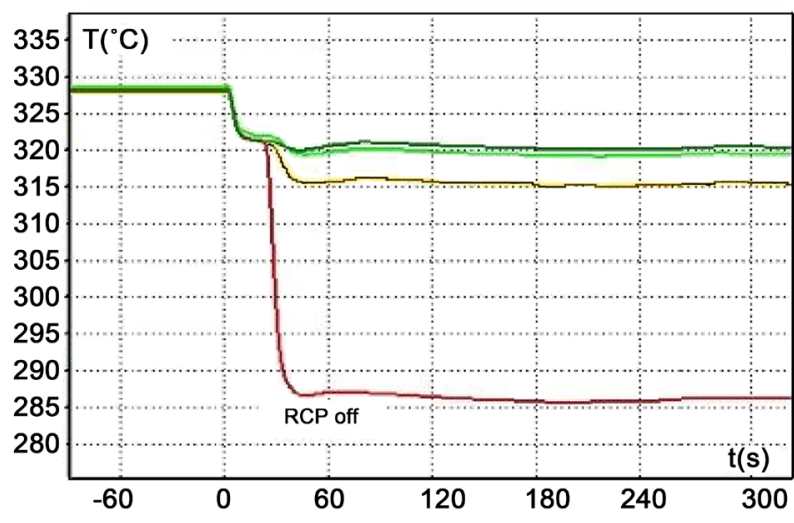

(b)

Figure 8. (a) Changes of coolant average temperature in hot legs measured in VVER-1000 [6]; (b) Changes of coolant average temperature in hot legs simulated by the simulator. 


\subsection{Real-Time Simulation of Movement of Control Rod Banks}

In the design of control and protection systems (CPS), the drives of control rods are grouped into 12 groups (banks) which can be controlled independently. The group banks \#1-8 are for protection and banks \#9-12 are for control and protection. Banks \#9-12 are used to control reactor power following scram or power setback signals sent by automatic controller as mentioned above. When reactor is operating at rated power, all of control rod groups are in the top position above the core, except for group \#12. At full power, this bank is maintained within the control range, at the core height from $70 \%$ to $95 \%$ [9]. This is similar to group \#10 in VVER-1000 [6].

The design requirement for control rods drop into the core is from 1.2 to $4.0 \mathrm{~s}$ after reactor SCRAM actuation [9]. In the transient, bank \#7 was fully inserted into the core from $100 \%$ to $0 \%$ within 4 seconds as observed in the simulator (Figure 9(b)). According to the measurement system established at the NPP, the positions of control rod bank are given with respect to the position of the lower end switches. In the simulator, they are located at $380 \mathrm{~cm}$ higher than the bottom of the reactor core. The length of the reactor core is $373 \mathrm{~cm}$ and the position of control rod corresponds to the bottom of the core. That means at $100 \%$ insertion of control rod the indicator is zero as seen in HMI of the simulator.

The difference in movements and positions of control rod banks in VVER1000 and VVER-1200 should be investigated in more detail. However, it is seen that the position of bank \#10 for VVER-1000 changes corresponding to power change (Figure 9(a)) while in case of VVER-1200 NPP simulator, Figure 9(b) shows that the control rod bank \#7 dropped into the core to lower the reactor power within 4 seconds and after 10 seconds from first position of $317.2 \mathrm{~cm}$ (83\%), bank \#12 moves down to compensate with power decreasing tendency, then after stabilization of temperature in reactor core bank \#12 reached the last stable position of $327 \mathrm{~cm}$ (86\%). In average, the moving speed of bank \#12 is about $2 \mathrm{~cm} / \mathrm{s}$ and compatible with design [9].

As mentioned above, although there are minor changes in NSSS designs between VVER-1200 and VVER-1000 reactor, the results obtained on the simulator

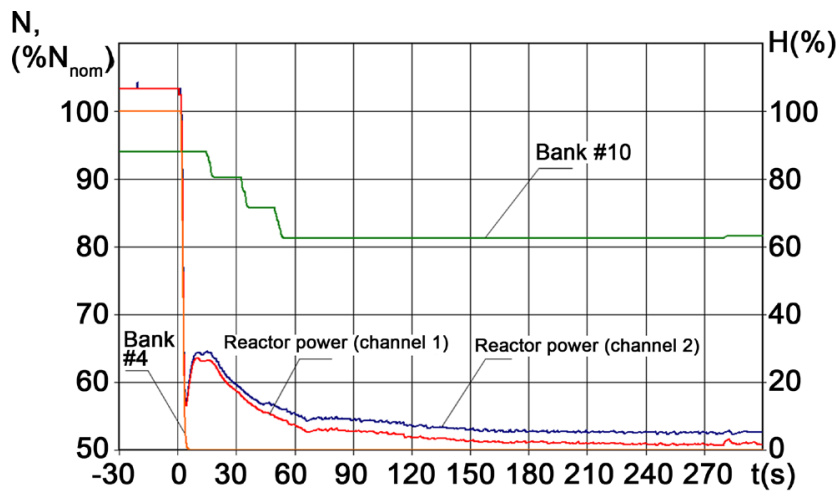

(a)

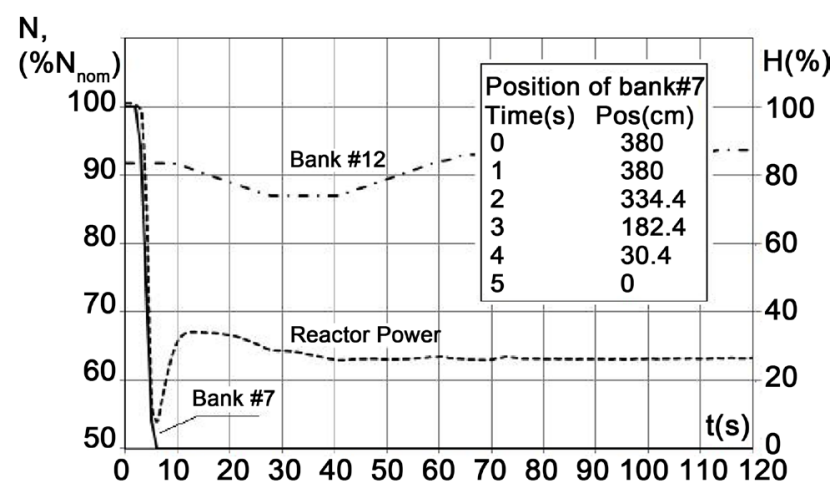

(b)

Figure 9. (a) Changes of reactor power and positions of CR banks \#4 and \#10 measured in VVER-1000 [5]; (b) Changes of reactor power and positions of CR banks \#7 and \#12 simulated by the simulator. 
are in good agreement with the experiment and design data.

\subsection{Axial Offset and Reactor Stability}

During normal operation and transients, the control rod banks are moved in their control range to maintain power distribution within the predefined limits. The axial offset $(\mathrm{AO})$ is defined as difference between power density in the upper and lower pats of the core with the current reactor power. Value of AO higher than recommended range may result in non-uniformity of the neutron flux and axial xenon oscillations, the occurrence of which will negatively affect the time duration for reaching stabilization of the reactor. Under certain circumstances, non-uniformity of the neutron flux in the reactor core can lead to transient situations. Therefore, for the safety and efficient operation of the reactor it is necessary to minimize the deviation of $\mathrm{AO}$, especially when reactor power is $80 \%$ of nominal power or higher [8]. The variation of $\mathrm{AO}$ in this case and the limits for VVER reactor [15] are shown in Figure 10(a) and Figure 10(b), respectively. The variation of about $\pm 0.2 \%$ is quite acceptable in comparison with $\pm 5 \%$ as recommended.

The mismatching of the turbine-generator load and the reactor power at the beginning of transient results in the change of steam pressure in the SGs and in the main steamline. The vapor pressure change in the SGs is given in Table 3. Three seconds after RCP switched off, as PZR pressure decreased to the set point of heater, heater group \#1 is on. The heater groups \#3, 4 are on when set points reached within 13 seconds. This results the increase of primary pressure as seen in Figure 11(b). After 30 seconds the heater groups \#3, 4 are off and primary pressure became stable.

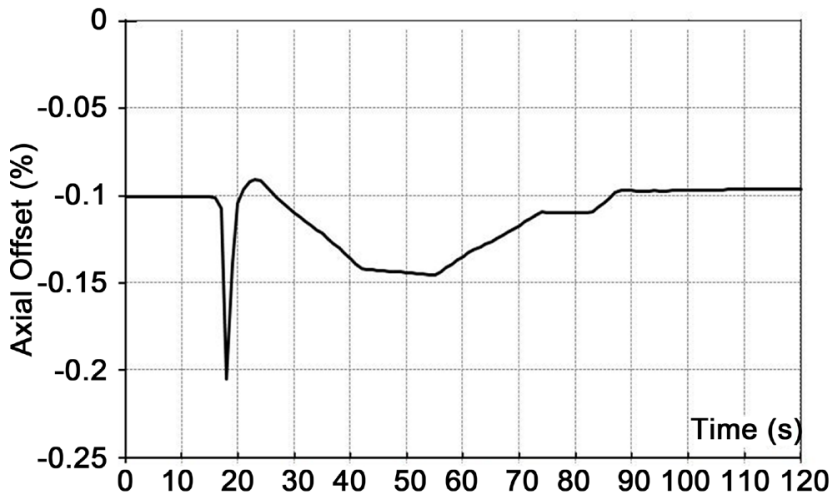

(a)

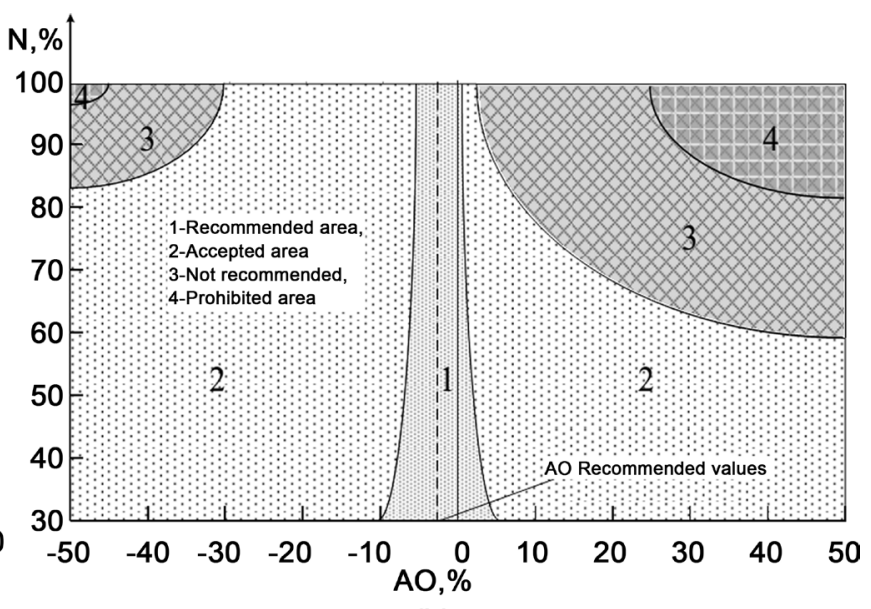

(b)

Figure 10. (a) Axial Offset in RCP coast-down transient in the simulator; (b) Recommended AO domain values depending on the power level of the VVER reactor [15].

Table 3. Pressure change in the SGs.

\begin{tabular}{ccc}
\hline Parameter & Simulator & PSAR [9] \\
\hline Loops with operating RCPs, MPa & 6.95 & 7.0 \\
Loop \#3 with switched off RCP, MPa & 6.78 & 6.8 \\
\hline
\end{tabular}




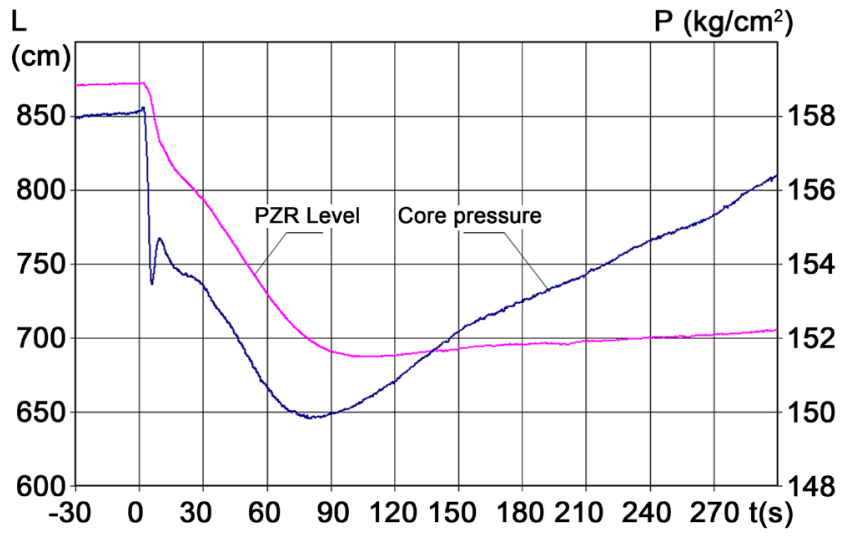

(a)

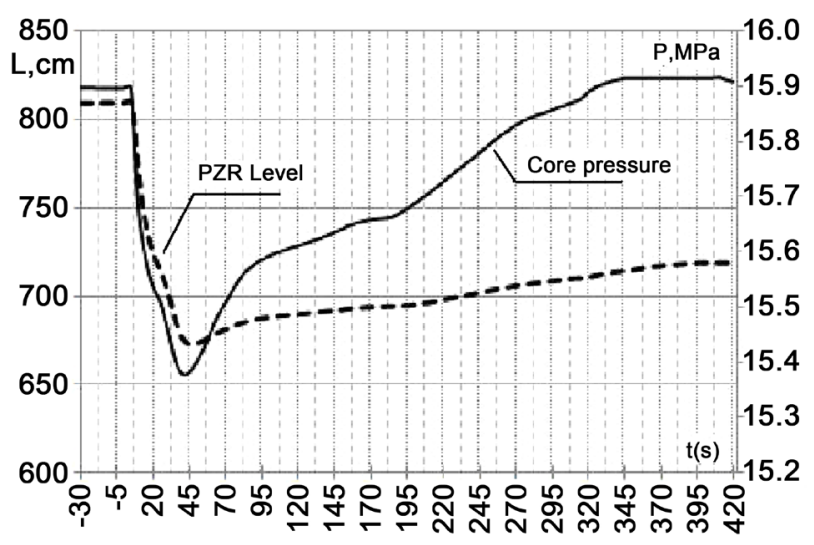

(b)

Figure 11. (a) The changes of water level in PZR and Core pressure measured in VVER-1000 [6]; (b) The changes of water level in PZR and Core pressure simulated by the simulator.

The coolant flow through a loop \#3 (RCP switched off) into the upper plenum does not influence on the coolant flow on the opposite side due to the fact, that the azimuthal angle between the two neighboring loops of one half is $55^{\circ}$, the angle to the next loop is $125^{\circ}$ (Figure 3). However, this makes change in upper plenum average temperature due to the reverse flow from cold leg to hot leg of loop \#3, especially the change in the upper plenum average temperature results in the change of water level in PZR (Figure 11(a), Figure 11(b)).

\section{Conclusions}

The verification has been performed to check the VVER-1200 NPP simulator by comparisons main parameters in nominal power operation with design data given in safety analysis report of VVER-1200/V392M [9] as well as Ninh Thuan FSSAR [8]. A good agreement was found between VVER-1200 NPP simulator and VVER-1200/V392M's PSAR.

The thermal hydraulic parameters in case of RCP coast-down transient simulated are given in comparison with VVER-1000 experiment data [6]. The axial offset which is a quantitative measure of the reactor stability has been considered.

The difference in control rod numbers and groups divided in VVER-1000 and VVER-1200 as well as automatic control procedures may lead to the different response of working bank \#12 as observed. There is the similar insertion of protection control rod bank \#4 (VVER-1000) and bank \#7 (VVER-1200). Further studies on the control and protection systems of VVER-1200 should be performed to confirm their validity.

A good agreement in tendency between the measured and simulated results shows that the thermal hydraulic characteristics and the control protection system are modeled in a reasonable way in the simulator. A real-time process is verified in which drop time of control rod banks is within a range specified by design. As the results, it is concluded that the implementation of the simulator is not only used for education and training, but also for R\&D with better understanding of operation processes and safety systems in modernized VVER nuclear reactors. 


\section{Acknowledgements}

The authors would like to thank Oleg Ivanov, WSC, USA and Alexander Markov, institute of NPP Operation Support, Kiev, Ukraine for their supports and recommendations during working on the simulator. In particular, the authors would like to show their gratitude to Vietnam Atomic Energy Agency (VAEA) and Vietnam Atomic Energy Institute (VINATOM) for providing valuable conditions to conduct this work as well as their special assistance in completing this paper. Useful discussions with colleagues in the simulator group at Nuclear Training Center, VINATOM are acknowledged. This work was supported by Ministry of Science and Technology of Vietnam under grant number 01/2017/ HD-DT/NLNT and partly DTCB.13/16/TTNTC.

\section{References}

[1] International Atomic Energy Agency (IAEA), Status report 108-VVER-1200 (V-491). IAEA/ARIS. 2013.

http://www.iaea.org/NuclearPower/Downloadable/aris/2013/36.VVER-1200(V-491. pdf

[2] Lozano, M.E., Moreno, R., Cedillo, A.L. and Sanjurjo, M.N. (2000) Assessment of a Reactor Coolant Pump Trip for TRILLO NPP with RELAP5/MOD3.2. NUREG/ IA-0177. U.S. Nuclear Regulatory Commission (NRC), March 2000.

[3] USNRC Technical Training Center, Westinghouse Technology Systems Manual. USNRC HRTD. Rev 10/08. http://www.nrc.gov/docs/ML1125/ML11251A015.pdf

[4] Grundmarin, U., Kiem, S., Kozmenkov, Y., et al. (2003) Transient Simulations in VVER-1000-Comparison between DYN3D-ATHLET and DYN3D-RELAP5. Proceedings of the 13th Symposium of Atomic Energy Research, Hungary, IAEA/ INIS-SK-2003-033.

[5] Tereshonok, V.A., Nikonov, S.P., Lizorkin, M.P., Velkov, K., Pautz, A. and Ivanov, K. (2009) Kalinin-3 Coolant Transient Benchmark-Swiching-off of One of the Four Operating Main Circulation Pumps at Nominal Reactor Power. NEA/NSC/ DOC (2009)5, OECD.

[6] Tereshnok, V.A., Stepanov, V.P., Zhukov, A.G., Salnikov, A.A. and Lebedev, O. (2009) The Studies of Operating Conditions Involving a Loss of a Single Reactor Coolant Pump out of Four Running Reactor Coolant Pumps with Fast Power Reduction System Actuation during Rostov Unit 1 Operation at Slightly Increased Reactor Rated Power. The 6th International Conference on Safety Assurance of NPPS with WWER, OKB.GidroPress, Podolsk, 26-29 May 2009. (In Russian)

[7] Povarov, V.P. (2017) The First Unit of New Generation VVER-1200: The Commissioning Features. Novoronhez AES, 2-2017. (In Russian)

[8] Thanh, T.C., et al. (2015) Studies to Support Basic Design Review of NPP Technologies Proposed for Ninh Thuan 1\&2 NPP Projects. KC.05.26/11-15. (In Vietnamese)

[9] Novovoronezh NPP-2 Unit No.1. Preliminary Safety Analysis Report. Chapter 4: Reactor. Rev.2. Atomenergoproekt, JSC. 2011.

[10] Kukshonov, A. (2012) ROSATOM Energy Solution: Engineering Perspective. Seminar on Russian Nuclear Energy Technologies \& Solutions, Johannesburg, 2-3 April 2012.

http://studylib.net/doc/18076538/state-corporation-"rosatom"-npp-construction-pr ojects 
[11] Western Service Corporation, Generic VVER Type Simulator-User Manual. WSC, Jan 2015.

[12] Akbashev, I.F., Piminov, V.A., Banyk, G.F., et al. (2010) Review of VVER-1000 and AES-2006 RPVs. IAEA Technical Meeting on Irradiation Embrittlement and Lie Management of Reactor Pressure Vessels, Znojmo, 18-22 October 2010.

[13] International Atomic Energy Agency (IAEA), Use of Control Room Simulators for Training of Nuclear Power Plant Personnel, IAEA-TECDOC-1411. Vienna. September 2004.

[14] Miettinen, J. (2008) Nuclear Power Plant Simulators: Goals and Evolution. Seminar on the Transfer of Knowledge Gained through CSNI Activities in the Field of Thermal-Hydraulics, Pisa, 5-9 May 2008, THICKET 2008-Session III-Paper 07, 107-133.

[15] Maximov M.V., Beglov K.V. and Kanazirski N.P. (2015) Control of Axial Offset in Nuclear Reactor during Power Transient. Automation Technological and Business-Processes, 7, 54-61. (In Russian)

\section{Scientific Research Publishing}

Submit or recommend next manuscript to SCIRP and we will provide best service for you:

Accepting pre-submission inquiries through Email, Facebook, LinkedIn, Twitter, etc. A wide selection of journals (inclusive of 9 subjects, more than 200 journals) Providing 24-hour high-quality service User-friendly online submission system Fair and swift peer-review system Efficient typesetting and proofreading procedure Display of the result of downloads and visits, as well as the number of cited articles Maximum dissemination of your research work

Submit your manuscript at: http://papersubmission.scirp.org/ Or contactwjet@scirp.org 